\title{
Solar Photovoltaic Systems in the Built Environment: Today Trends and Future Challenges
}

\section{Anju Singh}

National Institute of Solar Energy, Department of Solar Thermal, Gurugram, Haryana 122003, India

\section{Anies Mutiari}

Center for Material and Technical Product, Ministry of Industry of Republic Indonesia, Jl. Sangkuriang 14, 40135 Bandung West Java, Indonesia

\section{Cynthia Alexander}

Seychelles Energy Commission, PO Box 1488, Palms Street, Victoria, Mahe, Seychelles

\section{Diana Arteta De La Cruz}

Pontifical Catholic University of Peru, Av. Universitaria 1801, San Miguel, Lima 32, Peru

\section{Federico E. del Pozo Jr}

Industrial Technology Development Institute of Science and Technology,

DOST Compound, Bicutan, Taguig City, Philippines

\section{Rokas Valancius*}

Kaunas University of Technology, Faculty of Civil Engineering and Architecture,

Studentu st. 48, LT-51367 Kaunas, Lithuania

*Corresponding author: rokas.valancius@ktu.lt

\section{$\Gamma$} crossef http://dx.doi.org/10.5755/j01.sace.23.2.21268

Over the last decade, the research trends on PV systems are mainly focused on improving reliability, efficiency, and power quality, reducing the cost, integrating at various scales with a grid and contributing to development of microgrid and smart grid solutions. At the same time, many companies in recent years have been focusing on building-integrated PV systems, solar flowers, solar roadways, solar street lights and other innovative solutions for the built environment.

This paper presents a review of the past and present status, as well as the future challenges of solar photovoltaic technology in the built environment. The main focus in the paper is put on a current technology, contemporary research trends and future challenges. The various aspects related to the global renewable energy sources and the PV markets, the cost and technology of photovoltaic modules are addressed and discussed.

Keywords: renewable energy sources (RES), photovoltaic (PV) systems; building-integrated PV systems (BIPV), PV prices.

\section{ktu}

Journal of Sustainable Architecture and Civil Engineering Vol. 2 / No. 23 / 2018 pp. $25-38$ DOI 10.5755/j01.sace.23.2.21268 
Currently the most energy systems are based on burning of fossil fuels that are still dominating worldwide. However, fossil fuels are nonrenewable and emit directly greenhouse gases to the environment. This has been leading to serious environmental and health impacts (Malinowski et al. 2017). Furthermore, in a lot of countries the fluctuating price of fossil fuels has serious impact on the energy security.

There are several alternative resources that can provide clean, continuous, and renewable energies such as: solar, wind, biomass, hydropower, and geothermal. The renewable energy sources (RES) are receiving significant attention worldwide as a sustainable alternative type of energy supply being an important sector of the global energy generation (Abu-Rub et al. 2014). RES meets $40 \%$ of the increase in primary demand and their explosive growth in the power sector marks the end of boom years for coal. The rapid deployment of solar photovoltaics (PV), led by China and India, helps solar to become the largest source of low-carbon capacity by 2040 (World Energy Outlook 2017).

RES is clean and environmental friendly resource; they play an important role in reducing greenhouse gas emissions. Investing in RES could help in reaching little to no global warming effects and gas emissions, which would help in improving public health and in protecting our environment (Ellabban et al. 2014). It improves human life quality by providing enormous and inexhaustible energy supply, with more jobs, and other economic benefits such as stable energy prices. The wide spread of RES has even more benefits than above mentioned economic, health, and environmental aspects.

In 1958, the US Navy finally let few small PV cell-powered radio transmitters go into orbit on the satellite called Vanguard I. By 1972, approximately 1000 satellites were running on solar power. This meant that more money was spent on improving PV cells. However, the PV cells were still too expensive for use on Earth. In 1971, the price of PV power was 200 times the price of regular electricity in the USA. At the end of 2017 the price for crystalline silicon cells was lower than $0.30 € / W$ (see the Fig. 1), which is 200 times less than 40 years ago. Since the first application in space missions, the solar PV technology has come a long way. All over the world, a breakthrough in costs was observed over the last years, following a decade of massive investment in research and deployment.

The PV systems today gather the highest global attention because of its numerous advantages:

- easy transportation and light weight;

_ easy design and installation;

- quiet energy conversion;

_ in most cases nice architectural visibility;

- long lifetime with less maintenance requirement compared to other RES technologies.

It is obvious, that the prices of PV systems are very important for the vast deployment. In Germany prices of a typical 10 to $100 \mathrm{kWp}$ rooftop PV system were around $14,000 € / \mathrm{kWp}$ in 1990 . At the end of 2016, such systems cost about 1,270 €/kWp. In 2018 prices of small (up to $10 \mathrm{kWp}$ ) domestic rooftop PV system in Lithuania have dropped below 1,100 €/kWp (ESO 2018, Terma 2018). This is a net-price regression of more than $90 \%$ over a period less than 30 year. The price drop on PV is expected to continue. From 2009 to 2015 , there was 56\% reduction in the total cost: $77 \%$ in the PV modules, $45 \%$ in inverter cost, and $44 \%$ in installation-related costs (Chung et al. 2015). In recent years prices dropped additionally up to $10 \%$ for each year. All this helped in promoting this technology worldwide as a possible alternative to all other energy sources, renewables, and traditional sources. Dropping prices of PV systems and a rising demand lured new players into the solar industry, including electric utilities, oil and gas companies.

During 2016, at least $98 \mathrm{GWdc}$ of solar PV capacity was added worldwide, it is the equivalent to the installation of more than 40,000 solar panels every hour. More solar PV was installed than the net capacity additions of fossil fuels and nuclear power combined. By the year's end, global solar PV capacity totaled at least 402 GW, see the Fig. 1 (REN21 2018). 


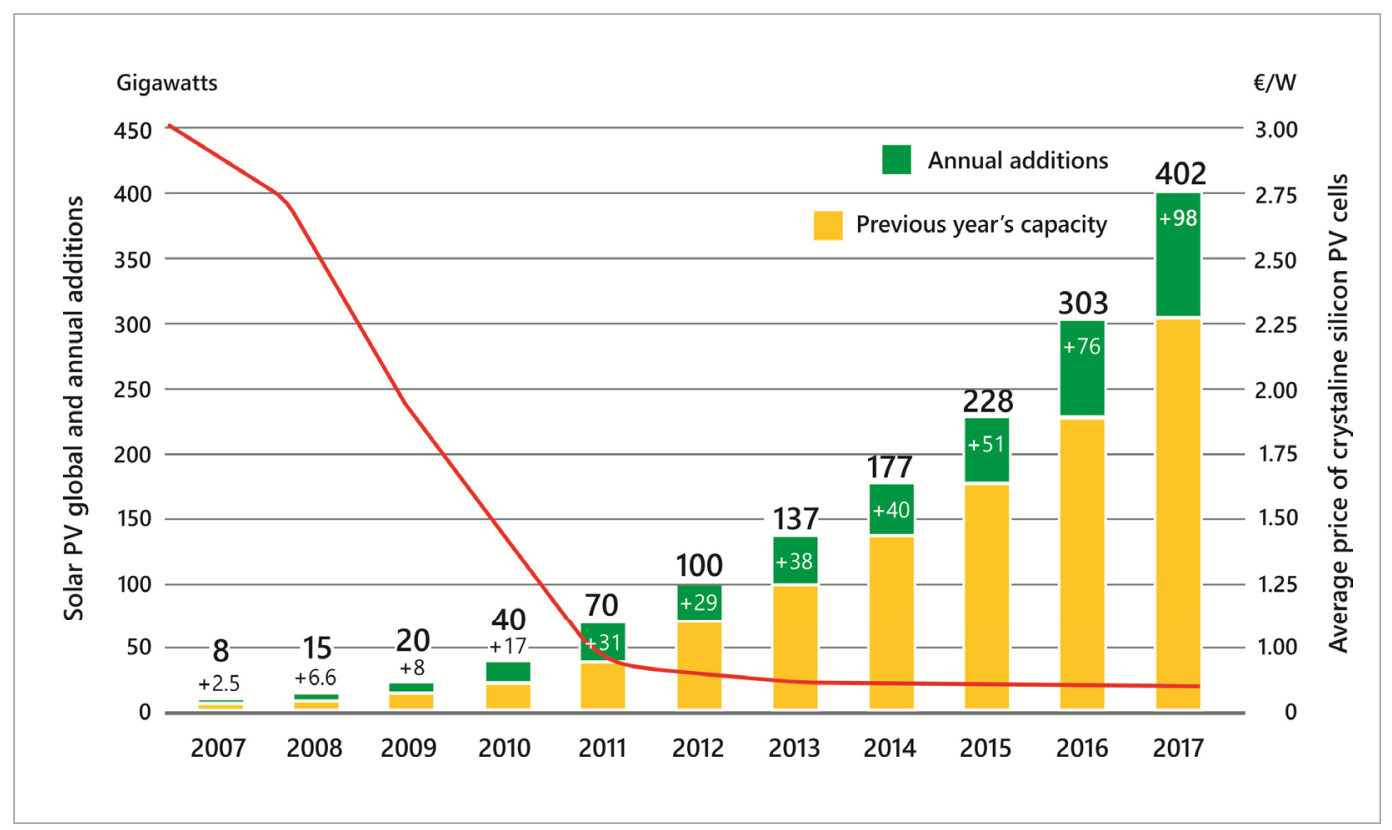

China, the United States, India, Japan and Turkey - were responsible for nearly $84 \%$ of newly installed PV capacity. The next five were Germany, Australia, the Republic of Korea, the United Kingdom and Brazil. For cumulative capacity, the top countries were China, the United States, Japan, Germany and Italy, with India not far behind. Despite the heavy concentration in a handful of countries, new markets are emerging and many countries have begun to contribute significantly to global growth. By the end of 2017, every continent had installed at least $1 \mathrm{GW}$ and at least 29 countries had $1 \mathrm{GW}$ or more of capacity. The leaders for solar PV capacity per inhabitant were Germany, Japan, Belgium, Italy and Australia (REN21 2018). Solar PV capacity in top 10 countries compared to population of country presented in Fig. 2.

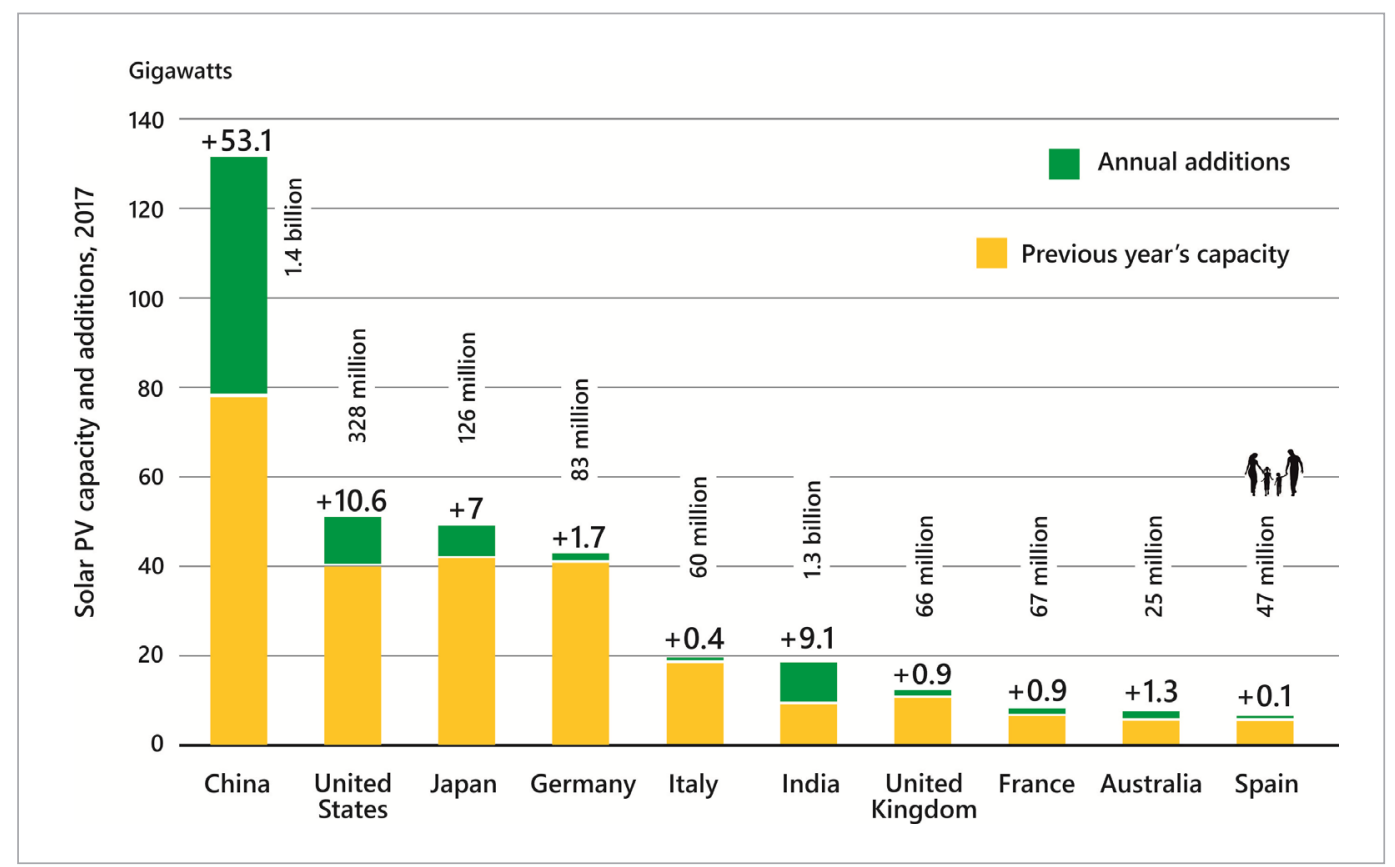

\section{Fig. 1}

The global capacity of the solar PV systems (REN21 2018) and average price of crystalline silicon PV cells 2007-2017

\section{Fig. 2}

The capacity of solar PV in the top 10 Countries, 2017 (REN21

2018) compared to population of country (Wikipedia 2018) 
The grid-connected solar PV is the most promising technology for solving future energy demands. The researches related to PV are currently concentrated on the improvement and solutions for higher efficiency and lower price of the PV panels and systems, as well as capturing the maximum possible amount of energy from the PV panels (Femia et al. 2012). Also the researches focus on power electronic converters for standalone and grid connections, development of efficient PV power converter topologies, solutions of challenges of power quality with grid-tie systems, reliable and cost-effective storage, and integration with smart grid systems [Adefarati and Bansal 2016; Zhou et al. 2015; Alam et al. 2015].

In most countries, the grid-connected solar PV system has promising reduction to be competitive with the popular energy sources. The main application of solar energy systems is to act as clean power source connected to the electrical grid (Romero-Cadaval et al. 2015).

However, there are many additional applications of solar energy, that can be very perspective in different countries, such as: solar water pumps, agrophotovoltaics systems, solar feeding of the telecommunication base towers, solar energy in building managements systems, solar energy in microgrids, smart grid, charging infrastructures of electric vehicles; solar energy for marine, satellite, and many other applications.

The aim of this paper is to review the past and the present status and future challenges of different solar PV systems focusing on PV systems in the built environment all over the world.

The general scheme of PV systems

PV cells arranged into panels can be used in largescale PV projects. A rooftop PV system can comprise few or hundreds of panels, while a large-scale project may consist of thousands or even millions of panels.

PV systems are generally classified according to their functional and operational requirements, their component configurations, and how the equipment is connected to other power sources and electrical loads. The two principal classifications are on-grid (grid-connected) systems and off-grid (standalone) systems.

Typical components of a solar PV system (see the Fig. 3) and their functions:

_ Solar PV modules or solar panels. These panels convert light (i.e. photo) into electrical power (voltage). Different technologies and efficiency of PV cells are described below.

- An inverter, the brain of a PV system serves primarily two purposes: to convert the DC power generated from solar panels into AC power that is used by our electrical appliances; to

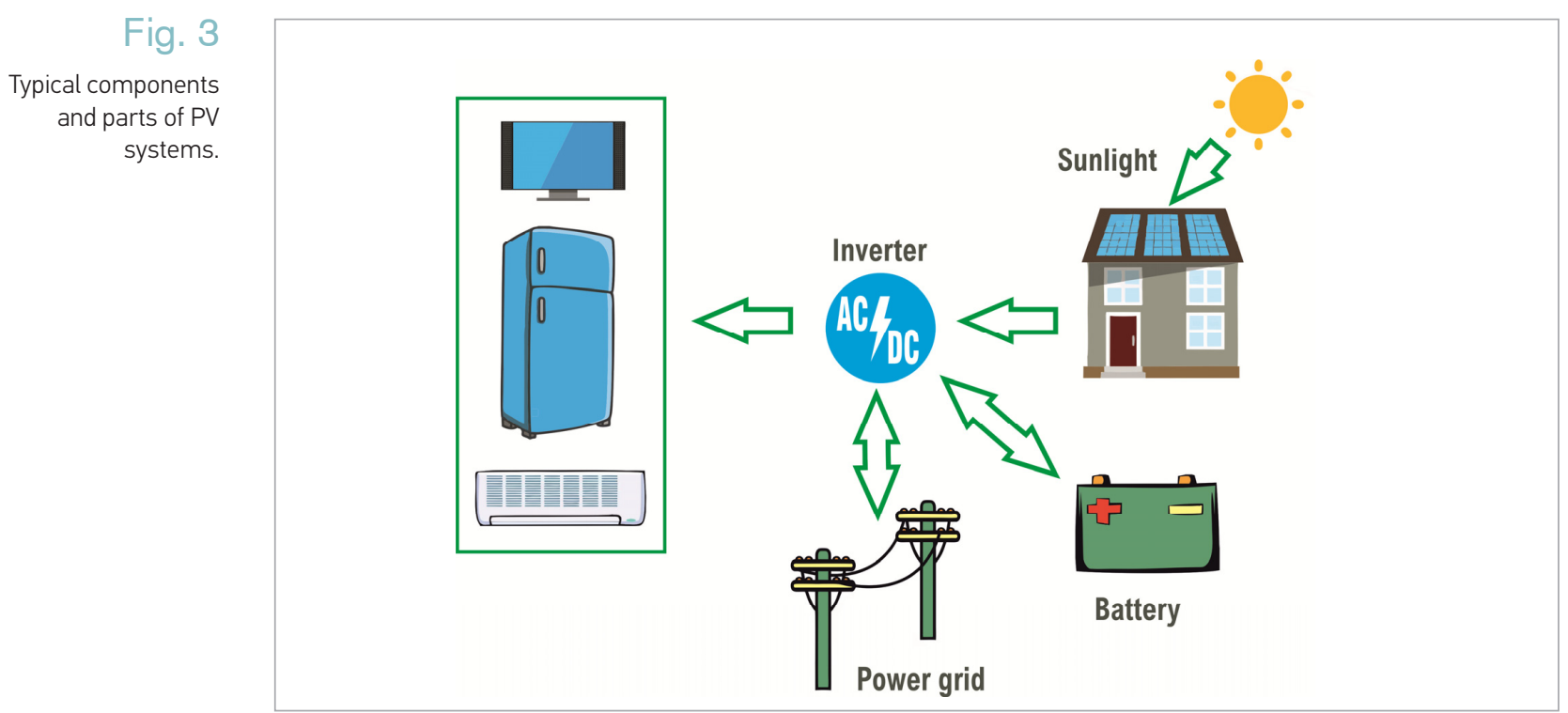


ensure that solar power generated is used at priority over grid supply. Solar inverters are essentially on-grid or off-grid/hybrid. The on-grid inverters are directly connected to the grid supply. The off-grid or hybrid inverters are connected to the specific loads to be run.

- A battery. Batteries are required to make power available in the absence of sun in off-grid PV systems. Batteries are an optional component for on-grid installations.

Mounting structures. These are fixtures that hold the solar panel in place (a roof, ground, etc.). Their appropriate design is essential to make sure, the panels get maximum sunlight.

Electrical and safety equipment. The different parts of PV system are connected by cables on $\mathrm{DC}$ and $\mathrm{AC}$ side. It is also important to install safety equipment. Electrical surges or short circuit can damage the equipment. Proper earthing and equipment like residual current circuit breaker, surge protectors, lightening arrestors, etc. are required.

These components are same all over the world. However, based on the region of your residence, the type of used components may vary. PV systems have a long life. Therefore, it is important to emphasize on quality and safety for durable performance.

\section{$\mathrm{PV}$ cells}

The PV cell (solar cell) is made from solid-state material that converts the energy of light (photons) into the electric form using the PV effect.

There are different types of materials used for the design of PV cells. The crystalline materials used for cells design are single crystalline (sc-Si) with a Czochralski (CZ) float zone (FZ) technology; multicrystalline (mc-Si) with a cast, sheet, ribbon growth technology; polycrystalline ( $\mathrm{pc}-\mathrm{Si}$ ) with a chemical-vapor deposition technology; and microcrystalline (mc-Si) with a plasma deposition. The main difference between these materials is the regularity level and structure, which affects the size of the crystals making such material.

There are other types of solar cells such as thin film, including amorphous silicon (a-Si), cadmium telluride (CdTe), and copper indium gallium selenide (CI(G)S) (Lee and Ebong 2015). Additional types may also be found such as desensitized solar cells (DSSCs), gallium arsenide germanium (GaAs) solar cells, luminescent solar concentrator (LSC) cells, multijunction (MJ) solar cells, organic solar cells (OPV), perovskite solar cells, photoelectron chemical cells (PECs), plasmonic solar cells, plastic solar cells, polymer solar cells, quantum dot solar cells, etc.

Next to these PV technologies, a wide range of colorful PV cells are now available on market and will open new opportunities for PV systems in the built environment, where not only efficiency or price are most important factors.

The output power of PV panels is sensitive to the environmental conditions such as solar irradiation intensity, ambient temperature and dust. The efficiency of commercial PV panels is still relatively low, but in the last decade, the efficiency of average commercial wafer-based silicon modules increased from about 12\% to 17\% (Super-mono 21\%). At the same time, efficiency of the CdTe module increased from $9 \%$ to $16 \%$. In the laboratory, best performing modules are based on monocrystalline silicon with $24.4 \%$ efficiency. The record efficiencies demonstrate the potential for further increase of efficiency at the production level. The record lab cell efficiency is $26.7 \%$ for mono-crystalline and $22.3 \%$ for multi-crystalline silicon wafer-based technology. The highest lab efficiency in thin film technology is 21.7\% for CIGS and 21.0\% for CdTe solar cells (Photovoltaics report 2018).

Nowadays in a laboratory, high concentration multi-junction solar cells achieve an efficiency to $46.0 \%$. With the concentrator technology, module efficiencies have been increased to $38.9 \%$. Still a lot of research and development is required in this direction. The record efficiencies demonstrate the need for further improvement of efficiency at the production level. This is a major challenge for future research to increase potentially the efficiency of PV panels at production scale with a reasonable price. Si-wa- 
fer based PV technology accounted for about $94 \%$ of the total production in 2016. The share of multi-crystalline technology is now about 70\% of the total production (Photovoltaics report 2018).

\section{On-grid PV systems}

The grid-connected PV systems have been the most popular during the last decade because they are much cheaper compared with the off-grid PV system. On-grid systems don't require expensive battery systems and other equipment. The grid-connected PV systems can be divided into three different groups:

High-power PV plants are now installed extensively worldwide and represented $61 \%$ of the PV market during 2015. Over the last decade, the maximum power of a single PV plant has increased from $50 \mathrm{MW}$ to more than $500 \mathrm{MW}$ in 2017. The biggest PV plant in the world is in Benban, Egypt with a total capacity of $1.8 \mathrm{GW}$. The park is set to start working at its full capacity at the beginning of 2019.

Residential and industrial PV applications, when the power of the PV system is lower than $50 \mathrm{~kW}$ approximately, the cost of the power converter is still the key but other issues such as efficiency, energy yield, and distributed operation gain importance.

- Low-power PV systems, which are usually hundreds of watts (or even in the kilowatt) range and the PV converter design has to be in this case mainly focused on achieving very high efficiency to a single-phase grid. Usually, the power converter is directly connected to a single PV module or a small PV array.

\section{Off-grid PV systems}

The off-grid PV power systems in recent years has lost their share in total cumulative PV capacity of the global market due to dynamic development of the grid-connected systems. The market share of standalone PV systems over the last 15 years reduced from 15\% in 2000 to below $0.5 \%$ in 2015 (Trends 2016 in Photovoltaic Applications, 2016). However, this part of PV application has important social aspects because there are still 1.2 billion people all over the world living without access to the electric grid, and PV is the most important power source for them (Off-Grid Solar Market Trends Report 2018). For those people, particularly standalone PV installations have become a viable solution for creating hybrid systems with energy storage and gas/diesel generators as part of bigger islanded microgrids (Protogeropoulos et al. 2006; Kojima et al. 2007). The issue of transforming to smart grid and solving the problems in rural areas is becoming more attractive for research and deployment. Generally, standalone PV applications can be divided into the following:

_ Pico PV systems $(P \leq 10 \mathrm{Wp})$, lanterns and simple multi-light systems (which may enable mobile charging);

_ Domestic PV systems (10 Wp $<\mathrm{P} \leq 10 \mathrm{kWp})$;

_ Commercial/institutional PV systems ( $>10 \mathrm{kWp})$.

The pico segment's estimated growth of overall market in terms of units sold has recently slowed. While slowing growth rates are natural for a sector that, as of 2016, had a base of over 90 million cumulative devices sold (including close to 30 million affiliate devices), the sharp decline was still surprising (Off-Grid Solar Market Trends Report 2018). The other off-grid domestic and commercial PV installations are not similarly impressive. Their share was $70 \mathrm{MW}$ in 2015, while the cumulative capacity was $1 \mathrm{GW}$. This share is very minor in comparison to $195 \mathrm{GW}$ of total cumulative capacity of grid-connected installations. Leading countries in standalone systems are China, Australia, Japan and Spain (Trends 2016 in Photovoltaic Applications, 2016).

Energy storage systems (batteries) can be classified as small local (up to $50 \mathrm{kWh}$ ) and distributed (with capacity above $50 \mathrm{kWh}$ ). Usage of energy storage systems supporting power system 
in last decade was based respectively on sodium-sulphur, nickel-cadmium, advanced lead-acid, redox-flow, and lithium-ion batteries. In recent years, the situation changed with significantly increased installations based on lithium-ion batteries, when compared to others, but existing capacity is still low. Future investment and installation in energy storage is promising. Many forecasts show multiple annual power market capacity increase in the next years and price drop of batteries from 350-750 €/kWp in 2017 to $200 € / \mathrm{kWp}$ in 2019 (PV magazine 2017). However, that is not enough for vast development of off-grid or hybrid systems.

The modern built environment creates numerous challenges for the deployment of PV technology. In one hand, sometimes it is technically very difficult to install PV systems in an existing built environment, on the other hand the large structures that dominate the skyline of every city create compactness, which, in turn, limits the available rooftop area and creates unpredicted shading patterns.

Researchers are exploring a number of unconventional solar applications that could promise to transform the PV industry; some of them are described below.

\section{Building-integrated PV systems}

While the installation of PV panels on flat and tilted roofs is perhaps the most popular example of its application in buildings, the building-integrated PV systems (BIPV), also offer tremendous potential. BIPV in new and existing structures offers great possibilities for the design of energy efficient and ecologically sound buildings, without compromising comfort or aesthetics. In addition to design benefits, BIPV offers several cost benefits. BIPV panels generate electricity and act as part of the building fabric. This combined function can result in costs savings where the cost of traditional building fabric is comparable to that of the PV panels. Also, no additional land or separate support structure is required, giving further cost advantages.

BIPV helps designers to meet goals of sustainability and reduced emissions while maintaining or improving comfort. The synergy between BIPV main functions of on-site energy generation and forming part of the building fabric, along with increasing cost competitiveness makes BIPV an especially attractive option.

The wide range of BIPV solutions offered in the market helps develop sustainable buildings: glass solar tiles (solar roof), pure curtain wall, ventilated, cold, warm, climate, second skin and triple skin facades, etc.

The wide range of colourful PV cells (green, orange, yellow, light red, dark red, light blue, dark blue, light grey dark grey, purple, white, black, etc.) are now available on the market and will open new opportunities of integrating artistically BIPV systems.

\section{Solar street lights}

Solar streetlight has become a trending because it provides illumination after daylight without addition to the demand on electricity. Modern streetlight uses high-intensity discharge lamps and low-pressure sodium (Rea et al., 2009). Despite their tremendous heat produce and abundance of illumination this type of lighting entails to a huge electricity requirement. When the solar streetlight was introduced, LED lighting system has been incorporated. This enabled street light manufacturers to maximize the lifetime of battery since LED's are low consumption lightings. The basic components of solar streetlight are solar panel, lighting fixture, rechargeable battery and its pole. In case of weather disturbances, solar streetlight maybe on its disadvantages since the capacity of solar charging of battery may be not enough to sustain overnight. This dilemma can be answered by using a grid-tied solar streetlighting that is invented in the US by Michael Hodulik. Instead of relying on the charged battery, the grid-tied solar streetlight may be supplied by the distribution line. Hybrid system is also an advantage for solar streetlighting (Lagorse, 2009). This practical type of solar streetlight uses solar and wind energy as a main supply for streetlighting. For instance, if

\section{PV systems in the built environment}


the solar panel didn't produce enough solar energy, the wind turbine will compensate to sustain the charging of battery.

\section{Floating PV systems}

Rooftop or ground installations are not the only options for solar modules. Developers have now designed systems that can float on channels, lakes or ponds. Compared with traditional terrestrial PV systems, floating PV systems can save a lot of land and water resources and obtain higher power generation efficiency. Based on the water cooling effect, the efficiency of floating PV systems can increase by about 1.58-2.00\% compared with traditional terrestrial PV systems (Luyao et al. 2017). However, in the case of seawater environment like lagoons or oceans, there are concerns on corrosion, humidity and cleaning the salt deposition frequently.

The influence of floating PV systems on the ecological environment such as water quality should be carefully examined. In addition, the infrastructure needs to be planned and developed to facilitate the development of floating PV systems. The floating PV power generation technology today is still a new type of power generation technology and there are still a lot of issues worth studying. Despite that in recent years around $1 \mathrm{GW}$ of capacity has already been installed around the world. China is a leading country with their construction of floating PV farm with a capacity of $40 \mathrm{MW}$ in an abandoned coal mine of China's Anhui Province. Till the end of 2017 the world's only seawater floating PV farm was located at Maldives.

\section{Solar roadways}

Onyx Solar has developed the first anti-slip, "walkable" PV paver in the world. PV pavers allow building owners to install solar energy on rooftops, while preserving their habitability (Onyx Solar, 2018). Traditional PV panels take up all the space on the roof, reducing the amenity space within any building. In contrast, the PV pavers let an owner generate free electricity, while still letting people enjoy the space and walk on top of them, safely. The PV pavers can be manufactured using any of the solar technologies (amorphous silicon and crystalline silicon), and they comply with the highest and most stringent quality standards.

They are intended for pedestrian traffic only, and they are installed as any technical, raised outdoors flooring system (PVC pedestals, wood and metal framing). They withstand up to $400 \mathrm{Kg}$ (point load), can be manufactured in standard dimensions, and customized ones.

\section{PV trees}

Solar Trees (see the Fig. 4) is an environmental enterprise, an ecological sculpture that aims to promote awareness to sustainability within the community. It is an independent unit that produces electricity and provides a place of comfort and energy for a wide variety of services, such as: free Wi-Fi, docking stations for smart phones and other electric devices, a water cooler with fresh running drinking water, trough for pets, illumination by night (Solargiving, 2018).

Recently a simpler version of PV tree concept (PV public space service) was presented by Lithuanian company Suneco. A PV public space service stop consists of $250 \mathrm{Wp}$ solar panel and $100 \mathrm{Ah}$ batteries. An integrated solution provides a wide range of options tailored to needs and purposes.

\section{Solar flowers}

The solar flower (SmartFlower) name comes from its design - the solar cells are arranged on individual "petals" that open at the beginning of each day (see the Fig. 4). After the sun goes down, the SmartFlowers petals fold up and a self-cleaning process kicks in. In addition to solar cells, the SmartFlower system contains a dual-axis tracker that makes it possible for its "petals" to follow the sun across the sky throughout the day. Thanks to this tracking capability, the SmartFlower can produce significantly more electricity than a similarly-sized rooftop solar panel system - up to 

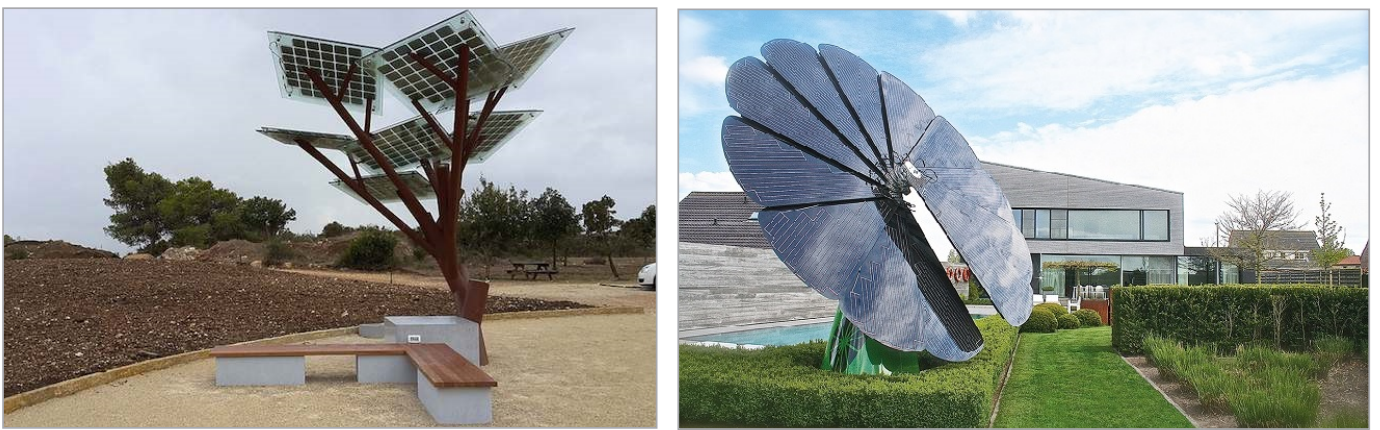

Fig. 4

PV tree and solar flower (producers photos)

51 percent more (Starflower Solar 2018). The 12-petal, $18 \mathrm{~m} 2$ structure comes with 2.5 kilowatts $(\mathrm{kW})$ of electricity production, which is equivalent to a standard $4 \mathrm{~kW}$ fixed rooftop array.

However, investments for the solar flower are about 50\% bigger compared to similar size rooftop solar panel system. SmartFlower buyers pay a price premium for the folding, self-cleaning, and aesthetic benefits of the SmartFlower over competing alternatives (SmartFlower solar: the complete review 2017).

Many developments over the last few years have affected the deployment of RES, including the lowest prices of PV systems, the decision of several countries to become coal-free, new policies and partnerships, carbon pricing, and new initiatives and goals set by governments at all levels.

\section{The European Union and Lithuania case}

The European Union (EU) RES directive (2009/28/EC) sets a binding target of 20\% final energy consumption from renewable sources by 2020. To achieve this, the EU countries have committed to reaching their own national renewables targets ranging from 10\% in Malta to $49 \%$ in Sweden. The 2017 report states that the EU totally achieved 16\% share of RES in 2014. In 2016, the estimated share of RES in the EU's gross final energy consumption was 17\% (the progress of each country will be fully assessed in the coming months). The vast majority of EU countries are well on track to reach their 2020 binding targets for RES (European commission, 2018). For example, Lithuania have reached 23\% share of RES in 2014. Public interventions such as support schemes remain necessary to make certain RES technologies competitive. To avoid distorting energy prices and the market however, these schemes should be time-limited and carefully designed. The EU has issued guidance on support schemes to help governments when they design or revise support schemes (European commission, 2018).

For example, in Lithuania, some limited subsidy systems and funds for RES installations exist since 2005. Depending on a project, it is possible to apply for a subsidy covering from 30 to $100 \%$ of initial costs. For example, it is possible to get a subsidy up to $30 \%$ for a single-family building, up to $40 \%$ for a multifamily building and up to $100 \%$ for hospitals and public buildings. Development of domestic PV ( $\leq 10 \mathrm{kWp}$ ) systems is now one of the government targets in Lithuania. Since the end of 2017, the installation of grid connected PV systems in single-family houses are much simpler than before. It takes only up to 2 months for systems up to $5 \mathrm{kWp}$ and up to 6 months for PV systems up to $10 \mathrm{kWp}$. Price reduction of PV systems and government support helped to grow installations of residential PV systems.

\section{Philippines case}

In a developing country like the Philippines, access to energy is necessary to alleviate the economic status of the land as well as improving the lives of the poor. The Philippines is estimated to have a population of 102 million people and is considered a fast-growing economy in the world. In 
this regard, a huge amount of power is needed to sustain the economy. Coal is the main fuel used in the Philippines, therefore the Philippines is considered to be the highest in Asia when it comes to electricity costs. This establishes the potential of shifting to renewable energy. Locals are investing in PV panels and batteries for a simple light load. In addition, the Philippine government also committed to reduce carbon emission by $70 \%$ by 2030 and targeted $15.3 \mathrm{GW}$ of renewable energy. To promote the development of solar power in the Philippines, the government introduces the net metering regulations.

\section{India case}

India is projected to be the world's fastest-growing large economy for the rest of the decade, according to projections from the World Bank and the International Monetary Fund. It will also soon be the world's largest country by population. India is generating around $20.1 \%$ of the total generation through renewable sources. India has set an impressive target to generate $175 \mathrm{GW}$ through renewable sources by 2022; 100GW through solar, $60 \mathrm{GW}$ from wind, 10GW from biomass and waste and 5GW through small hydro. Out of $175 \mathrm{GW}, 62.84 \mathrm{GW}$ has been achieved till December 2017 (MNRE annual report 2017-18). A national solar mission was launched under the National Action Plan on Climate Change on June 30, 2008.

The government has set a massive target of 100GW under the National Solar Mission. To achieve the goal, the Indian government has started many schemes and programs under various categories of solar projects, from big PV parks to small rooftop and off-grid installations; for example, solar park scheme, defense schemes, solar water pump scheme etc. Not only that but, the central government of India is also providing financial assistance, starting from $30 \%$ to $60 \%$ subsidy on the rooftop PV plants and $60 \%$ to $70 \%$ on solar water pumps to promote solar energy. To accelerate the program government also gave targets to the organizations and states and introduced net metering. As a result, the cost of solar power has come down drastically, i.e., USD 0.36/ unit.

\section{Indonesia case}

Indonesia is the world's fourth largest country by population, encompasses more than 17000 islands. Indonesian growing need for energy security due to gradual depletion of fossil-based energy sources demands renewable, affordable and omnipresent energy sources. One of the most anticipated ways to secure the future country energy supply is to use the energy from the sun, which is delivered to earth in a formed light or electromagnetic radiation. In this regard, a photovoltaic device is especially of wide interest as they can directly convert sun's visible light into electricity. Taking into account the Indonesian geographical advantage where the solar irradiation is relatively unchanged in the values of $4.75-5.98 \mathrm{kWh} / \mathrm{m} 2 /$ day throughout the year (Rumbayan et al. 2012), PV would inevitably be of an essential part of country's electricity source. In this regard, Indonesian Government has launched Presidential Regulation No. 79/2014 to reduce significantly the use of oil to below $20 \%$ and to increase the contribution of RES from $0.5 \%$ to more than $5 \%$. In 2014, the energy mix in Indonesia for fossil fuels and RES were $94 \%$ and $6 \%$ while it is projected that the national energy mix target in 2025 for fossil fuels and RES are 75\%, and 25\% (Ministry of Energy and Mineral Resources of the Republic of Indonesia 2014).

However, so far only 20 MW were installed in 2014 and in 2015 the first utility-scale plants were connected to the grid. In early 2016 the government announced a 5 GW plan to develop PV in the country (Trends 2016 in Photovoltaic Applications, 2016).

\section{Seychelles case}

Seychelles as any other small island developing states, for generation of electricity rely on imported fossil fuel; about $95 \%$ of used fuel is imported and it covers more than $10 \%$ of the national 
annual budget, not to mention concerns on the impact to climate change. The national energy policy sets a target of achieving $5 \%$ RES deployment by 2020 and $15 \%$ by 2030. Currently Seychelles have $6 \mathrm{MW}$ capacity of wind turbines installed in two reclaimed islands and about 2.8 MW grid tied distributed rooftop PV systems. Presently a lot of projects are being developed in the country to reach the targets and the development of utility scale PV system on a sea water lagoon is considered.

The Seychelles RES market is accelerated by policy changes, established strong regulatory framework, improved capacity and financial incentives supporting the access to more renewable sources with limited land availability. Other technical concerns such as intermittency of resources, grid limitations, fluctuation and forecasting systems must be properly discussed and solved. The plan to explore other RES in marine are also on going but so far only in the research and development. 4MW floating PV Plant in the Providence Lagoon will be the first such project in country.

\section{Peru case}

In 2016 Peru generated 10.8\% from RES (small hydro, biomass, wind and solar) of its total 48.3 TWh. Large hydro accounted for $39.8 \%$, natural gas for $46.4 \%$, and coal, oil and diesel for the rest. To promote RES, Peru offers priority dispatch and $20 \%$ accelerated depreciation for renewables projects.

Peru has one of the highest solar resources in the world, receiving 2,050-2,550 kWh/m2 of solar irradiance per year. The opportunities for solar are diverse, with potential in large grid connected projects and mid-sized off-grid projects in mining and industry. Rural electrification also offers an opportunity for small scale solar PV. Peru, one of the first countries in the word, held an auction for off-grid solar in November 2014 to contract up to 500,000 off-grid PV systems to be installed in North, Center and South regions. The auction had only one winner, the private developer Ergon, which announced the intention to install 150,000-200,000 systems. On March 2018, the Peruvian government declared the opening of Rubí, the largest solar power plant in the country that boasts over half a million solar panels with a production capacity of 145MW.

According to the study (PUCP 2017) in 2017 over 500,000 homes in Peru had no access to electricity, that was much more prevalent in rural areas. Through the national rural electrification plan, it is planned to provide over 345,000 homes with PV panels in the near future. Peru goal of reaching $99 \%$ electrification by 2021 involves the installation of small scale PV systems for remote households without grid access. It is planned to invest $385 \$$ million for this purpose. However, despite these advancements, Peru is still lagging behind its South American neighbors when it comes to RES.

Over the recent decades environmental concerns have pushed up RES revolution. Recently the research trends of PV systems are mainly focused on improving reliability, efficiency and power quality, reducing the cost, integrating with a grid at various scales and contributing to building microgrid and smart grid paradigms.

The future trend of PV is promising with the objective of becoming one of the first energy producers of the world. The future of PV development strongly depends on efficiency and cost of solar modules. The usage of new materials to create multijunction solar cells will lead the future in this field.

Speaking about the solar PV power inverters, the focus will always be on maximizing the efficiency of converter with minimum cost. Reliability, fault-tolerant operation, easy maintenance, reduced transportation and installation costs are also factors in developing new power converter topologies for PV systems, from low to high power.

In addition, the stochastic behavior of the sun irradiation, the grid stability requirements, and the maximization of economical profits will possibly force us to use energy storage installations sup-

\section{Future challenges of PV systems development}


porting PV installations to save extra energy if a power curtailment is required or adding active or reactive power if the grid demands it. The development of battery technology by improving their lifetime, efficiency and reducing their weight, size and costs will walk hand in hand with this hybrid solution.

Another aspect, which can significantly improve future perspective of solar energy is broad development of DC smart grids as well as research on smart transformers (Liserre et al. 2016). This trend makes easy integration and full utilization of PV energy and storage elements possible, which eliminates additional power converters and improves overall efficiency and energy security.

Finally, yet importantly, the vast development of PV systems also strongly depends on governments and a strong support required developing and implementing RES. In the past tariff policies accelerated the development of the RES technology. Now, the political efforts have to be focused on creating a friendly scenario to create a distributed electrical grid system not very dependent on gas/coal-based or nuclear plants.

In recent years all over the world PV systems have become very competitive solutions for residential, commercial, and industrial applications for both standalone and grid connected operations.

In a lot of countries, the grid-connected solar PV is the promising technology for solving future energy demands. The researches related to PV currently concentrate on the improvement and solutions for higher efficiency and lower price of the PV panels and systems, extracting the maximum possible amount of energy from the PV panels. The best performing monocrystalline silicon models have about $26,7 \%$ efficiency. The high concentration multijunction solar cells achieved up to $46.0 \%$ efficiency in the laboratory. There is still much research and development needed in this direction. Recorded efficiencies demonstrate the need for further efficiency improvement at the production level. This is a major challenge for future research to increase the efficiency of PV panels at production scale with a reasonable price. Also battery systems, BIPV systems, floating PV systems, agrophotovoltaics systems, and other modern solutions of PV systems require a lot of issues worth studying.

Prices, efficiency of PV systems as well as adaptation in the built environment have a significant effect on PV deployment. On the other hand, the vast development of PV systems also strongly depends on the governments and the strong support is required to develop and implement RES.

\section{References}

Abu-Rub H., Malinowski M., Al-Haddad K., Power electronics for renewable energy systems, transportation and industrial applications. Hoboken, NJ, USA: Wiley; 2014. https://doi. org/10.1002/9781118755525

Adefarati T., Bansal R. C. Integration of renewable distributed generators into the distribution system: A review. IET Renewable Power Generation. 2016; 10(7): 873-884. https://doi.org/10.1049/iet-rpg.2015.0378

Alam M. K., Khan F., Johnson J., Flicker J. A comprehensive review of catastrophic faults in PV arrays: Types, detection, and mitigation techniques. IEEE Journal of Photovoltaics. 2015; 5(3): 982-997. https://doi.org/10.1109/JPHOTOV.2015.2397599
Chung D., Davidson C., Ardani R. F. K., Margolis R. U.S. photovoltaic prices and cost breakdowns: Q1 2015 benchmarks for residential, commercial, and utility-scale systems. NREL, Golden, CO, USA, Tech. Rep., 2015.

Directive 2009/28/EC. Available at: https://eur-lex. europa.eu/eli/dir/2009/28/oj [accessed 2 May 2018].

Ellabban O., Abu-Rub H., Blaabjerg F. Renewable energy resources: Current status, future prospects and their enabling technology. Renewable and Sustainable Energy Reviews. 2014; Vol. 39: 748-764. https://doi.org/10.1016/j.rser.2014.07.113

ESO 2018. Available at: http://www.eso.lt/lt/ 
namams/elektra/paslaugos_1723/saules-jegainesirengimas.html [accessed 28 May 2018].

European commission 2018. Available at: https:// ec.europa.eu/energy/en/topics/renewable-energy [accessed 4 May 2018].

Femia N., Petrone G., Spagnuolo G., Vitelli M. Power electronics and control techniques for maximum energy harvesting in photovoltaic systems. Boca Raton, FL, USA: CRC Press, 2012.

International renewable energy agency 2015. Battery storage for renewables: Market status and technology outlook. 2015. Available at: www.irena. org [accessed 5 May 2018].

Kojima Y., Koshio M., Nakamura S., Maejima H., Fujioka Y., Goda T. A demonstration project in Hachinohe: microgrid with private distribution line. In Proc. IEEE International Conference on Control Science and Systems Engineering. Apr. 2007; 1-6. https:// doi.org/10.1109/SYSOSE.2007.4304276

Lagorse, J., Paire, D., Miraoui, A. Sizing optimization of a stand-alone street lighting system powered by a hybrid system using fuel cell, PV and battery. Renewable Energy, 2009; 34(3): 683-691. https://doi. org/10.1016/j.renene.2008.05.030

Lee T. D., Ebong A. Thin film solar technologies: A review. In Proc. 12th International Conference on High-capacity Optical Networks and Enabling/ Emerging Technologies. Dec. 2015; 1-10. https:// doi.org/10.1109/HONET.2015.7395441

Liserre M., Buticchi G., Andresen M., Carne G. D., Costa L. F., Zou Z. X. The smart transformer: impact on the electric grid and technology challenges. IEEE Industrial Electronics Magazine. 2016; 10(2): 46-58. https://doi.org/10.1109/MIE.2016.2551418

Luyao L., Qinxing W., Haiyang L., Hailong L., Qie S., Wennersten R. Power generation efficiency and prospects of floating photovoltaic systems. Energy Procedia. 2017; 105: 1136-1142. https://doi. org/10.1016/j.egypro.2017.03.483

Malinowski M., Leon J. I., Abu-Rub H. Solar photovoltaic and thermal energy systems: current technology and future trends. Proceedings of the IEE, 2017; 105(11): 2132-2146. https://doi.org/10.1109/ JPROC.2017.2690343

MNRE annual report 2017-18. Ministry of new and renewable energy. Government of India. Annual Report 2017-18. Available at: https://mnre.gov.in/ file-manager/annual-report/2017-2018/EN/index. html [accessed 28 May 2018].

Off-Grid Solar Market Trends Report 2018. Available at: https://www.lightingafrica.org [accessed 2 May 2018].
Onyx Solar 2018. Available at: https://www.onyxsolar.com/product-services/photovoltaic-glass-solutions/pv-floor [accessed 10 May 2018].

Photovoltaics report. Fraunhofer institute for solar energy systems, ISE with support of PSE conferences \& consulting GmbH Freiburg, 26 February, 2018.

Protogeropoulos C., Tselepis S., Neris A. Research issues on stand-alone pv/hybrid systems: stateof-art and future technology perspectives for the integration of grid topologies on local island grids. In Proc. 4th World Conference on Photovoltaic Energy Conversion, vol. 2. May 2006; 2277-2282. https:// doi.org/10.1109/WCPEC.2006.279627

PUCP 2017. Available at: http://gruporural.pucp. edu.pe/nota/el-desarrollo-de-la-energia-solar-enel-peru/ [accessed 2 May 2018].

Solar Magazine 2017. Available at: https://www. pv-magazine.com/2017/08/03/lithium-ion-batteries-below-200kwh-by-2019-will-drive-rapidstorage-uptake-finds-ihs-markit/ [accessed 4 May 2018].

Rea, M., Bullough, J., Akashi, Y. Several views of metal halide and high-pressure sodium lighting for outdoor applications. Lighting Research \& Technology. 2009; 41(4): 297-320. https://doi. org/10.1177/1477153509102342

REN21 2018. Renewables 2018 global status report. Paris: REN21 Secretariat. 2018.

Reid G., Julve J. Second Life-batteries as flexible storage for renewable energies. Federal association for renewable energy (BEE), Hannover messe, Lower Saxony, Germany, Apr. 2016.

Romero-Cadaval E., Francois B., Malinowski M., Zhong Q.C. Grid connected photovoltaic plants: An alternative energy source, replacing conventional sources. IEEE Industrial Electronics Magazine. 2015; 9(1): 18-32. https://doi.org/10.1109/ MIE.2014.2362211

Rumbayan M., Abudureyimu A., Nagasaka K. Mapping of Solar Energy Potential in Indonesia using Artificial Neural Network and Geographical Information System. Renewable and Sustainable Energy Reviews. 2012; 16 (3): 1437-1449. https://doi. org/10.1016/j.rser.2011.11.024

Terma 2018. Available at: http://www.terma.lt/ Saules-elektrines [accessed 28 May 2018].

Trends 2016 in photovoltaic applications, in photovoltaic power systems programme, 21st ed. Int. Energy Agency (IEA) Paris, France, 2016.

Wikipedia 2018. List of countries and dependencies 
by population. Available at: https://en.wikipedia. org/wiki/List_of_countries_and_dependencies_ by_population [accessed 24 September 2018].

World energy outlook 2017, International Energy Agency (IEA), Paris, France, 2017.
Zhou Q., Xun C., Dan Q., Liu S. Grid connected PV inverter reliability considerations: A review. in Proc. 16th International Electronic Components and Technology Conference., Aug. 2015; 266-274. https:// doi.org/10.1109/ICEPT.2015.7236590

\section{About the} Authors

\section{ANJU SINGH \\ Researcher}

National Institute of Solar Energy, Department of Solar Thermal

Main research area

Solar thermal

\section{Address}

Gurugram, Haryana 122003, India

Tel. +918800440147

E-mail: anshihari@gmail.com

\section{ANIES MUTIARI}

Researcher

Center for Material and Technical Product, Ministry of Industry of Republic Indonesia

\section{Main research area}

Emerging material for photovoltaics

\section{Address}

Jl. Sangkuriang 14 Bandung West Java Indonesia 40135 Tel. +62 222504088

E-mail: anies-m@kemenperin.go.id
CYNTHIA ALEXANDER

Principal officer

Seychelles Energy Commission

Main research area:

Renewable energy, energy efficiency in buildings, efficient appliances, standards and labeling, energy auditing

Address

PO Box 1488, Palms Street, Victoria, Mahe, Seychelles Tel. +248 2723459

E-mail: calexander@sec.sc

\section{DIANA ARTETA DE LA CRUZ}

Researcher

Pontifical Catholic University of Peru

\section{Main research area:}

Renewable energy for the development of rural communities.

\section{Address}

Av. Universitaria 1801, San Miguel, Lima 32 - Peru Tel. +511944264875

E-mail: diana.arteta@pucp.edu.pe
FEDERICO E. DEL POZO JR

\section{Lecturer}

Industrial Technology

Development Institute of Science and Technology

\section{Main research area}

Energy management, renewable energy, energy engineering, electrical engineering, ergonomics, work measurement

\section{Address}

DOST Compound, Gen. Santos Avenue Bicutan, Taguig City,

Philippines, 1631

Tel. +632 8372071

E-mail: fedjr14@gmail.com

\section{ROKAS VALANCIUS}

\section{Lecturer}

Kaunas University of Technology, Department of Building Energy Systems

\section{Main research area}

Renewable energy, indoor climate, energy performance in buildings

\section{Address}

Studentu st. 48, LT-51367 Kaunas, Lithuania Tel. +37068010000

E-mail: rokas.valancius@ktu.lt 